Western University Scholarship@Western

Centre for the Study of International Economic

Centre for the Study of International Economic

Relations Working Papers

Relations

1985

Testing Interest Rate Parity and Rational Expectations for Canada and the United States

Allan W. Gregory

Follow this and additional works at: https://ir.lib.uwo.ca/economicscsier_wp

Part of the Economics Commons

Citation of this paper:

Gregory, Allan W.. "Testing Interest Rate Parity and Rational Expectations for Canada and the United States." Centre for the Study of International Economic Relations Working Papers, 8503C. London, ON: Department of Economics, University of Western Ontario (1985). 
ISSN 0228-4235

ISBN $\quad 0-7714-0611-8$

THE CENTRE FOR THE STUDY OF INTERNATIONAL ECONOMIC RELATIONS

WORKING PAPER NO. $8503 \mathrm{C}$

TESTING INTEREST RATE PARITY AND RATIONAL EXPECTATIONS

FOR CANADA AND THE UNITED STATES

Allan W. Gregory

Department of Economics Library

JAN 231985

University of Western Ontario

This paper contains preliminary findings from research work still in progress and should not be quoted without prior approval of the author.

DEPARTMENT OF ECONOMICS

THE UNIVERSITY OF WESTERN ONTARIO

LONDON, CANADA

N6A 5 C 2 


\title{
TESTING INTEREST RATE PARITY AND RATIONAL EXPECTATIONS \\ FOR CANADA AND THE UNITED STATES
}

\author{
Allan W. Gregory ${ }^{*}$ \\ University of Western Ontario \\ Department of Economics \\ London, Ontario \\ Canada \\ N6A $5 \mathrm{C} 2$ \\ December 1984
}

\begin{abstract}
The purpose of this paper is to test a 'weak' form of the joint hypothesis of interest rate parity and rational expectations for Canada and the United States. Since the parity equation with rational expectations is itself a partial difference equation, standard solution techniques give rise to a set of testable nonlinear restrictions. The results indicate that the restrictions imposed by rational expectations upon the interest rate parity equation are supported by the data up to the end of the 1970's. However, when the 1980's observations are included in the sample, the hypothesis is rejected. There is evidence to suggest that the process governing the interest rate differential has changed in the 1980 's and that this may account for the rejection.

* The author would like to thank David Backus, Zvi Hercowitz, David Longworth, Michael McAleer, Tom McCurdy, Maurice Obstfeld and Michael Veall for helpful comments.
\end{abstract}

Department of Economics Library

$$
\text { JAN } 231985
$$

University of Hestern Ontario 
TESTING INTEREST RATE PARITY AND RATIONAL EXPECTATIONS

FOR CANADA AND THE UNITED STATES

\section{Introduction}

The joint assumption of uncovered interest rate parity and rational expectations has provided a convenient link between international financial assets in many theoretical open economy models. Although this assumption is not without appeal, there has been little research to establish its acceptability on empirical grounds. The tests that have been done are Indirect in the sense that they have employed the substitution method (see Cumby and Obstfeld, 1981). 1 For this approach, the expected value of the future spot rate is replaced by its actual future value and, under the null hypothesis of uncovered interest rate parity and rational expectations, the ex post residuals from the parity equation should not be significantly different from white noise. A test of the null hypothesis then involves examining these residuals for serial correlation using various portmanteau tests.

In general, these tests have detected serial correlation and accordingly, the authors have rejected the joint hypothesis of interest rate parity and rational expectations. An advantage of this testing procedure is that it is 'model-free'; that is, no attempt is made to model the movements in exchange rates or the interest rate differential. However, this absence of modelling is not without costs. For instance, these tests provide little information as to why the null hypothesis has been rejected and consequently they cannot indicate where specific weaknesses in the theory may lie. The substitution method of testing interest rate parity and rational expectations is much like a light switch--on/off. Unfortunately when the switch is off, we are often left in the dark. On the other hand, given that under rational expectations the interest rate parity equation is 
itself a partial difference equation, a direct and more informative test is afforded by solving the equation using standard techniques and then testing the overidentifying rational expectations restrictions against the data. Of course, the usefulness of these tests must be evaluated in the context of the particular model presented.

One other important consideration in the substitution method of testing is the assumption that the interest parity relation itself holds identically and deterministically. This is a crucial restriction for this procedure. However, Sims (1982) has argued that asset markets are never exactly in equilibrium but, instead asset prices vibrate randomly around equilibrium. Yet, if we relax this deterministic condition and permit serially independent mean zero departures from interest rate parity, then the substitution method does indeed produce ex post residuals that are serially correlated even under interest rate parity and rational expectations. ${ }^{2}$ This is despite the fact the individual disturbances themselves are serially independent. Therefore the substitution method of testing interest rate parity and rational expectations breaks down whenever the deterministic assumption is dropped. ${ }^{3}$

The purpose of this paper is: (i) to specify and to estimate a simple model of exchange rate determination based upon interest rate parity and rational expectations using Canadian and United States month-end data; and (ii) to test the corresponding cross-equation rational expectations restrictions. We assume that interest rate parity holds up to a stochastic serially independent error term. This, together with the first differencing of the data which is done to achieve stationarity, implies that we are conducting a weaker test of interest rate parity and rational expectations than has traditionally been done. The intention here is to investigate whether there is some empirical support for a weaker hypothesis. In view of its widespread use theoretically, this strategy seems to have some merit. 
At least the present investigation will provide some evidence of how useful an approximation the joint hypothesis of interest rate parity and rational expectations is for Canada and the United States.

A key question of the testing is to determine whether the time-series representation of the interest rate differential process appears in the exchange rate equation in the form prescribed by interest rate parity and rational expectations. Another aspect considered in this study is to determine whether there have been periods of time for which the joint hypothesis of rational expectations and interest rate parity is a reasonable characterization. Therefore we examine whether conclusions based upon full-sample estimation continue to hold for various subperiods. 4 In this way we may investigate when the postulated model of exchange rate determination accurately describes the facts and when it does not. This may be especially helpful from the viewpoint of model building.

The results indicate that with the model cast in first differences, the rational expectations restrictions placed upon the interest rate parity equation are supported by the data up to the end of the 1970's. However, when the observations from the 1980's are included in the sample, the restrictions are rejected.

In Section 2 the model is developed and in Section 3 the results are presented. Concluding remarks are given in Section 4 .

\section{The Model}

Uncovered interest rate parity relates the expected change in the spot exchange rate to the interest rate differential on similar assets in the different currencies. This relation may be written as:

$$
s_{t}-E_{t} s_{t+1}=i_{t}^{*}-i_{t}+u_{t}, \quad i=1, \ldots, N
$$


where $s_{t}$ is the logarithm of the spot exchange rate at $t$ ime $t, E_{t}$ is the expectation operator conditional upon the information available at time $t$, $i_{t}$ and $i_{t}^{*}$ are the domestic and foreign nominal interest rates respectively and $u_{t}$ is a mean zero serially independent disturbance term. ${ }^{5}$ All variables are measured as deviations from their means. The fact that $u_{t}$ appears in equation (1) implies that we are assuming that interest rate parity holds up to a stochastic serially independent error term. Thus, we permit nonsystematic departures from interest rate parity and assume $E_{t} u_{t+j}=0$ for all $j=1 \ldots$.

In order to solve the partial difference equation (1), the data generating process for the interest rate differential, $z_{t}=i_{t}^{*}-i_{t}$, must be modelled. If we assume that the interest rate differential is stationary and ergodic, then by Wold's decomposition theorem, the process has an infinite moving average representation. ${ }^{6}$ Following Baillie, Lippens and McMahon (1983), we approximate the infinite moving average process by a finite autoregressive process of order p:

$$
z_{t}=\sum_{i=1}^{p} \varphi_{i} z_{t-i}+\epsilon_{t},
$$

where the roots of the polynomial in the lag operator, $1-\varphi_{1} L-\ldots-\varphi_{p} L^{P}$ lie outside the unit circle and $\epsilon_{t}$ is white noise.

Although we have chosen to model the interest rate differential as an autoregressive process, it is not our intention to suggest that Canadian interest rates are determined in a purely 'mechanical' way. To some extent and degree, the policy of the Bank of Canada over the seventies has been directed toward managing the nominal interest rates. While it is true that monetary policy in Canada has consistently focussed upon controlling the nominal interest rates, the justifications and the intended goals and benefits from doing so have changed. For example, in the early 1970's 
conventional widsom suggested that prudent management of interest rates would promote smoothly functioning financial markets and lead to healthy investment. However, in the mid-seventies, attention was directed towards the growth rate of certain monetary aggregates and a new argument for controlling interest rates was advanced. In particular, targets for growth in the narrowly defined money supply (MI) were to be achieved using interest rates as the policy instrument (see Bank of Canada Annual Report 1975). Nevertheless, even for the period of money targeting, there appeared to have been departures from stated policy. For instance, as noted by Courchene (1981), the Bank of Canada in 1978 became especially concerned with the dramatic depreciation of the Canadian dollar and took defensive action.

For our estimation period, it would have been extremely difficult to take into account all the considerations used by the Bank in establishing an interest rate. However, since Canadian interest rates have always tended to drift towards those that have prevailed in the U.S., a close approximation is provided by modelling the interest rate differential as a stationary autoregressive process. Evidence in Gregory and Raynauld (1984) suggests that the lagged interest rate differentials are important determinants of Canadian interest rates. Also, in the empirical application, we added a constant to equation (2). This allows a constant difference to persist between the interest rates in the long run. However, as in Gregory and Raynauld (1984), the constant never proved significant in estimation and was omitted from the analysis.

Assuming that $z_{t}$ is part of agents' information sets so that $E_{t} z_{t}=z_{t}$, the solution to the partial difference equation (1) is (see Gourieroux, Laffont and Monfort, 1982):

$$
s_{t}=\frac{\left(1+\varphi_{2} L+\ldots+\varphi_{p} L^{p-1}\right)}{\left(1-\varphi_{1}-\ldots-\varphi_{p}\right)} z_{t}+u_{t} \text {, }
$$


with $1-\varphi_{1}-\ldots-\varphi_{p} \neq 0 . .^{7}$ Rational agents take into account the process governing the interest rate differential when forecasting future spot exchange rates. This places testable restrictions upon the manner in which current and lagged interest rate differentials influence exchange rate movements. The unrestricted model corresponding to equation (3) is :

$$
s_{t}=\sum_{i=0}^{p-1} \alpha_{i} z_{t-i}+u_{t} .
$$

Notice that there are $\mathrm{p}$ non-linear restrictions placed upon the parameters of equations (2) and (4). Also we did add a constant to both the restricted and unrestricted equations but found it was never significant at conventional levels.

As we argued earlier, allowing an independent and identically distributed error term into the interest rate parity equation (1) negates the substitution method as a valid test procedure. To see this, consider the decomposition of the future spot rate into two orthogonal components:

$$
s_{t+1}=E_{t} s_{t+1}+\eta_{t+1}
$$

where $\eta_{t+1}=\left(s_{t+1}-E_{t} s_{t+1}\right)$ and is serially independent. For the present model under rational expectations this is :

$$
\eta_{t+1}=u_{t+1}+\frac{\epsilon_{t+1}}{1-\phi_{1}-\ldots-\phi_{p}} .
$$

The substitution method involves calculating an ex post residual $w_{t}$ as:

$$
w_{t}=s_{t}-s_{t+1}-z_{t}
$$

and testing whether this is serially independent using portmanteau tests. However, for our model we may obtain an explicit form for $w_{t}$ which is :

$$
\begin{aligned}
w_{t} & =u_{t}-\eta_{t+1} \\
& =u_{t}-u_{t+1}-\frac{\epsilon_{t+1}}{1-\phi_{1}-\ldots-\phi_{p}} .
\end{aligned}
$$


Clearly, $w_{t}$ is serially correlated even under the assumption that $E\left(u_{t} \varepsilon_{t}\right)=0$ for all $t$. The ex post residual in such a test is composed of a linear combination of two error terms, one of which is a firstorder moving average process with a unit root. Thus, the portmanteau tests should detect serial correlation even when the interest parity and rational expectations assumptions are true.

\section{Testing and Results}

Since the stationarity of the processes is essential, both the spot and interest differential were first differenced. Also, these first differenced variables were regressed against a constant and eleven seasonal dummies. The residuals from these two regressions were then taken as the relevant variables. Casting the variables in first differences implies that we are testing a weaker version of interest rate parity and rational expectations. In the past these kinds of transformation were often applied to test weaker forms of purchasing power parity.

Since innovations or shocks to the interest rate differential process are likely to be correlated with shocks to the foreign exchange market, we have allowed for a contemporaneous correlation between $\epsilon_{t}$ and $u_{t}$ in estimation. ${ }^{8}$ Letting $v_{t}^{T}=\left[u_{t} \varepsilon_{t}\right]$, we assume that $v^{N I D}(0, \Omega)$. The restricted model (equations (2) and (3)) is estimated by full information maximum likelihood (FIML). The nonlinear restrictions may be easily tested using a likelihood ratio test. To do this we estimate the unrestricted system (equation (2) and equation (4)) also by FIML and take twice the difference of the log likelihood obtained from unrestricted and restricted systems estimation. Under the null hypothesis of interest rate parity and rational expectations this is asymptotically distributed 
as $\chi^{2}$ with $p$ degrees of freedom. With regard to the properties of this testing procedure, Monte Carlo evidence in Hoffman and Schmidt (1981) and Gregory and Veall (1984) suggest that the likelihood ratio tests of the nonlinear rational expectations restrictions compared against the chisquare distribution have quite good small sample properties. Reasonable test results can often be obtained for data sets with as few as twenty observations.

The model was estimated using month-end data from 1972 (1) to 1982 (12) giving one hundred and thirty-two observations. The data were kindly supplied by the Bank of Canada and are available on request from the author. The spot exchange rate is a closing rate and two different sets of interest rates were tried. These were Canadian and American thirty-day Financial and Commercial Paper Rates (adjusted to monthly rates of return). Since the two sets of results are almost identical, we present only those using the Financial Paper rates.'

In Table 1 both the unrestricted (equations (2) and (4)) and the restricted (equations (2) and (4)) estimates from full-sample FIML estimation are presented. The appropriate order of the autoregressive process for the forcing variable $z_{t}$ was determined on the basis of a 1ikelihood ratio test of an order $p$ process versus one of $(p+1)$ and $(p-1)$ on the unrestricted model. The error structure was subsequently checked using the modified Box-Pierce portmaneau test (see Ljung and Box, 1978). According to this method, the appropriate order for the change in the interest rate differential process was $\mathrm{six}$.

The unrestricted results suggest that an increase in the rate of change of the U.S. interest rate relative to the Canadian rate implies a depreciation in the Canadian currency. The effect occurs immediately and lasts for about a half a year. Additional lagged values of the change of 
the interest rate differentials were never helpful in explaining movements in the change of the exchange rate. When the rational expectations restrictions are imposed (equation (2) and equation (3)), only $\phi_{4}$ is significantly different from zero at conventional levels. Moreover, the calculated statistic for the likelihood ratio test is 26.20 versus a critical value of 12.59 at the five percent level of confidence, thus indicating a resounding rejection of the rational expectations restrictions. ${ }^{10}$ However, the situation changes when we undertake subsample estimation.

We commenced by re-estimating the models (unrestricted and restricted) from 1972 (1) - 1974 (12) and testing the null hypothesis. The terminal date of 1974 was chosen because of the adoption by the Bank of Canada of a money-targeting policy in 1975. For this estimation period we found: (i) an autoregressive process of order one was satisfactory in explaining movements in the rate of change of interest rate differentials; and (ii) the restrictions imposed by rational expectations upon the interest rate parity equation were supported by the data. We then continued to re-estimate the models adding 12 months to the sample each time until we were able to reject the null hypothesis.

The largest sample period for which the hypothesis is not rejected is 1972 (1) - 1979 (12). These results are reported in the top half of Table 2. All the estimated coefficients are significant and the calculated statistic for the likelihood ratio test is 1.28 as compared to the critical value of 3.84 at the five percent level. When the 1980 observations are added (the bottom half of Table 2), the calculated statistic of 4.30 was obtained. Notice that the estimated coefficient for $\alpha_{1}$ is substantially larger than the one corresponding to the 1972 (1) - 1979 (12) period 11 
and that the estimated coefficient $\varphi_{1}$ from restricted estimation is not significant. Severe convergence problems were also encountered for unrestricted full-information maximum likelihood estimation when the 1980 observations were included. Adding the 1982 and 1982 observations produced similar conclusions. For these larger sample periods, not only were the rational expectation restrictions rejected but now higher orders for the autoregressive process for interest rate differential equations were required. A weak argument can be made that this change in the interest rate differential process indicates that Canadian nominal assets have become poorer substitutes for those in the United States. However, at present there are not enough observations available to estimate the model using only the 1980's data.

\section{Concluding Remarks}

The aim of this paper has been to specify, estimate and test a simple model of exchange rate determination based upon uncovered interest rate parity and rational expectations using Canadian/United States monthend data. With the variables expressed in first differences we tested a weaker version of interest rate parity. The evidence indicates that the restrictions imposed by rational expectations upon the interest rate parity equation are supported by the data up to the end of the 1970's. However, once the 1980's are included in the sample, the joint hypothesis of interest rate parity and rational expectations is rejected.

A possible explanation for the rejection using the most recent data is the change in the process governing the change in the nominal interest rate differentials. Although there is no 'hard' evidence, we might reasonably expect the existence of such instabilities. The 1980's have witnessed unprecedentedly high nominal interest rates with much larger 
differentials between Canadian/U.S. rates. We would expect that rational agents would not employ an unstable time-series representation to forecast the expected change of the future spot exchange rate. This shift in structure may in fact be due to a change in the risk premium associated with Canadian/U.S. nominal assets. With this in mind, it may be worthwhile modelling a risk premium in the interest rate parity equation along the lines of Domowitz and Hakkio (1983). It is evident that the 1980's are quite different from historical experience and hopefully, as more observations become available, we may be able to provide some concrete explanations.

Fina1ly, the existing evidence against interest rate parity and rational expectations based upon the substitution method may not be that compelling since the procedure does not yield a consistent test if the parity relation is stochastic. Certainly our results for the 1970 's suggest that the joint hypothesis is a closer approximation for Canada and the United States than what conventional wisdom might lead us to believe. 
TABLE 1

INTEREST RATE PARITY AND RATIONAL EXPECTATIONS:

$$
1972(1)-1982(12)
$$

\section{UNRESIR ICTED EST IMATES}

Equation 2

$z_{t}$

$\varphi_{1}=\begin{aligned}-0.1160 \\ (1.24)\end{aligned}$

$\varphi_{2}=\underset{(0.22)}{0.02000}$

$\varphi_{3}=\frac{-0.1663}{(2.33)}$

$\varphi_{4}=\frac{-0.2383}{(3.17)}$

$\varphi_{5}=\begin{gathered}-0.08723 \\ (0.99)\end{gathered}$

$\varphi_{6}=\underset{(2.02)}{0.1536}$

$D W=1.93$

$$
L=951.62
$$

\section{RESTRICTED ESTIMATES}

Equation 2 Equation 3

$z_{t}$

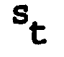

$$
\varphi_{1}=\frac{-0.1241}{(1.45)}
$$$$
\varphi_{2}=\frac{0.04322}{(0.56)}
$$$$
\varphi_{3}=\frac{-0.1155}{(1.70)}
$$$$
\varphi_{4}=\frac{-0.2144}{(3.05)}
$$$$
\varphi_{5}=\begin{gathered}
-0.9766 \\
(1.14)
\end{gathered}
$$$$
\varphi_{6}=\underset{(1.42)}{0.1494}
$$

$\mathrm{DW}=1.91 \quad \mathrm{DW}=2.08$

$$
L=938.52
$$

Note: Absolute t-statistics are given in parentheses. DW is the Durbin-Watson statistic intended solely for descriptive purposes, and $I$ is the log of the likelihood excluding the const ant. 
TABLE 2

INTEREST RATE PARITY AND RATIONAL EXPECTATIONS

UNRESTRICTED EST IMATES

RESTRICTED ESTIMATES

$1972(1)-1979(12)$

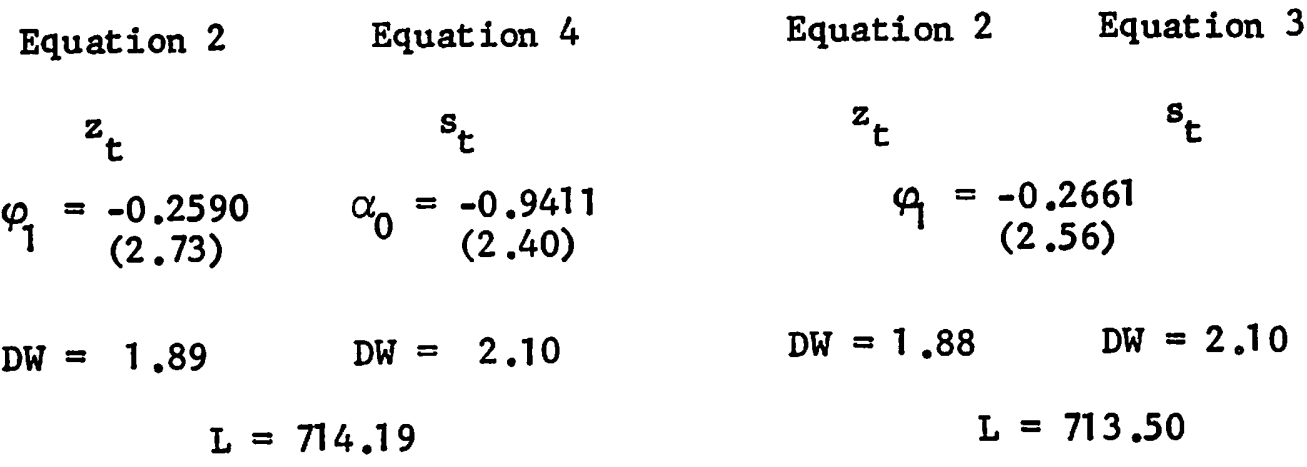

$1972(1)-1980(12)$

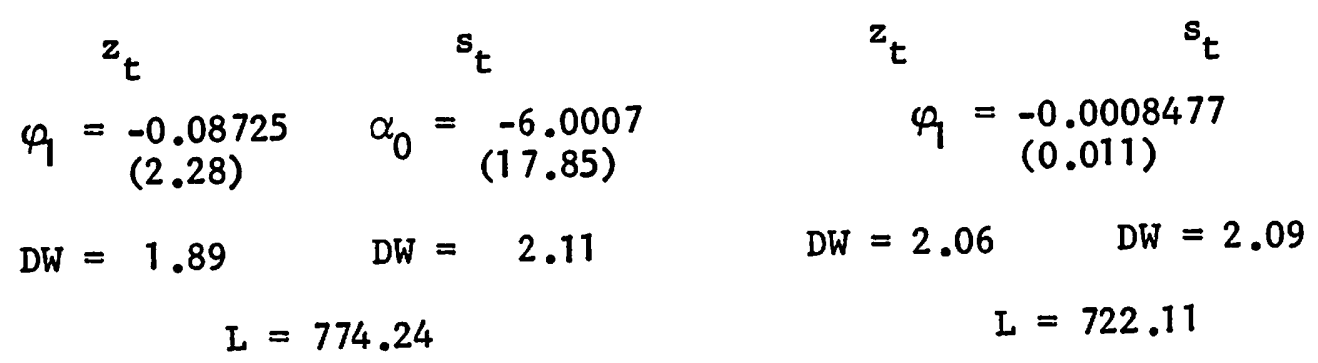

Note: Absolute t-statistics are given in parentheses, $D W$ is the Durbin-Watson statistic intended solely for descriptive purposes, and $I$ is the $\log$ of the likelihood excluding the constant. 


\section{Footnotes}

${ }^{1}$ This method is discussed in Nelson (1975), McCallum (1976) and more recently in Pagan (1983). In contrast Hakkio (1981) has estimated the restricted structure in testing the term structure of the forward premium.

2 For that matter whenever a structural equation is stochastic and the substitution involves a future variable (as in the interest parity relation) the subsequent residual in the equation is serially correlated (see Nelson, 1975 and McCallum, 1976). Recently Hayashi and Sims (1984) have proposed a potentially more efficient procedure for estimating these kinds of rational expectations models.

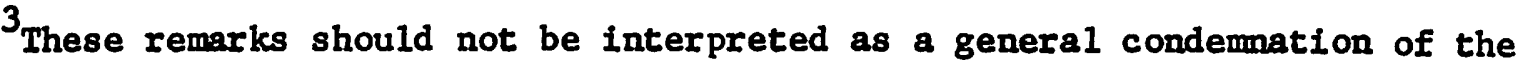
substitution method. Indeed quite the contrary is intended.' The substitution method often provides the simplest way possible in which to estimate many rational expectations models. The principal advantage lies in the fact that no particular model need be specified to generate the required expectations. Hence potential misspecification from using an 'incorrect' model can be avoided and the estimation problem becomes one of errors in variables.

${ }^{4}$ In a related study investigating the unbiasedness hypothesis in the forward foreign exchange market, Gregory and McCurdy (1984) have found that conclusions based upon full sample estimation could be very misleading. The estimates of the test equation could be very unstable and subsampling can give some indication of the robustness of the results.

${ }^{5}$ In accordance with rational expectations, we have assumed that it is the conditional mathematical expectation of the future spot rate that appears in equation (1). Also, we have assumed that there is no risk premium. We did 
add a constant to each equation considered, but it never proved significant in estimation. However, since the risk premium may be variable, it is not clear that this constant adequately captures this. See Gregory and McCurdy (1984).

${ }^{6}$ We note that tests used in the substitution method also require ergodicity and stationarity.

${ }^{7}$ Gourieroux, Laffont and Monfort (1982) have demonstrated that restricting $\left\{s_{t}\right\}$ to be a stationary series implies that the martingale part of the general solution is a constant sequence. This constant would be eliminated when the mean is removed.

${ }^{8}$ Equation (4) is exactly identified as there is one predetermined variable, $z_{t-p}$, which does not appear in this equation.

${ }^{9}$ Results using the 30-day Commercial Paper rates are available upon request.

10 f course, the usual caveat associated with rejecting any joint hypothesis applies: the rejection may be due to interest rate parity or it may be due to rational expectations or both.

${ }^{11}$ We note that given the negative sign and magnitude of $\varphi_{1}$ from umrestricted estimation for both periods, the estimated coefficient of $\alpha_{0}$ should be positive and greater than one according to equation (4). 


\section{References}

Baillie, R., R. E. Lippens, and P. C. McMahon (1983), "Testing Rational Expectations and Efficiency in the Foreign Exchange Market," Econometrica $51,553-563$.

Bank of Canada (1975), Annual Report of the Governor for 1975, Ottawa.

Courchene, T. J. (1981), Money, Inflation and the Bank of Canada, Volume III: An Analysis of Monetary Gradualism, 1975-1980, Montreal: C. D. Howe Research Institute.

Cumby, R. E. and M. Obstfeld (1981), "Exchange-Rate Expectations and Nominal Interest Differentials: A Test of the Fisher Hypothesis," Journal of Finance $36,697-704$

Domowitz, I. and C. S. Hakkio (1983), "Conditional Variance and the Risk Premium in the Forelgn Exchange Market," unpublished manuscript, Northwestern University, September, 25 pages.

Gourieroux, C., J. J. Laffont and A. Monfort (1982), "Rational Expectations in Dynamic Iinear Models: Analysis of the Solutions," Econometrica 50, 409-425. Gregory, A. W. and T. H. McCurdy (1984), "Testing the Unbiasedness Hypothesis in the Forward Exchange Market: A Specification Analysis," Journal of International Money and Finance 3, 357-368.

Gregory, A. W. and J. Raynauld (1984), "An Econometric Model of Canadian Monetary Policy Over the 1970's," Journal of Money, Credit, and Banking, forthcoming. Gregory, A. W. and M. R. Veal1 (1984), "A Lagrange Multiplier Test of the Restrictions for a Simple Rational Expectations Model," Canadian Journal of Economics, forthcoming.

Hakkio, C. S. (1981), "The Term Structure of the Forward Premium," Journal of Monetary Economics 8, 41-58.

Hayashi, F. and C. Sims (1983), "Nearly Efficient Estimation of Time Series Models with Predetermined, but not Exogenous Instruments," Econometrica 51, 783-798. 
Hoffman, D. L. and P. Schmidt (1981), "Testing the Restrictions Implied by the Rational Expectations Hypothesis," Journal of Econometrics 15, 265-287.

Ljung, G. M. and G. E. P. Box (1978), "On the Measure of Lack of Fit in Time Series Models," Biometrika 65, 297-303.

McCallum, B. T. (1975), "Rational Expectations and the Estimation of Econometric Models: An Alternative Procedure," International Economic Review 17, 484-490.

Nelson, C. (1975), "Rational Expectations and the Estimation of Econometric Models," International Economic Review 16, 555-561.

Pagan, A. (1983), "Econometric Issues in the Analysis of Regressions with Generated Regressors," International Economic Review 25, 221-247.

Sims, C. A. (1982), "Policy Analysis with Econometric Models," Brookings Papers on Economic Activity 1, 107-152. 
$\underline{1981}$

\begin{tabular}{|c|c|}
\hline $8101 C$ & $\begin{array}{l}\text { Markusen, James R. Factor Movements and Commodity Trade as Compliments } \\
\text { A Srrvey of some Cases. }\end{array}$ \\
\hline $8102 \mathrm{C}$ & $\begin{array}{l}\text { Conlon, R.M. Comparison of Australian and Canadian Manufacturing } \\
\text { Industries: Some Empirical Evidence. }\end{array}$ \\
\hline $8103 C$ & $\begin{array}{l}\text { Conlon, R.M. The Incidence of Transport Cost and Tariff Protection: } \\
\text { Some Australian Evidence. }\end{array}$ \\
\hline $8104 C$ & Laidler, David. On the Case for Gradualism. \\
\hline $8105 \mathrm{C}$ & $\begin{array}{l}\text { Wirick, Ronald G. Rational Expectations and Rational } \\
\text { Stabilization Policy in an Open Economy }\end{array}$ \\
\hline $3106 C$ & $\begin{array}{l}\text { Mansur, Ahsan and John Whalley Numerical gecification of Applied } \\
\text { General Equilibrium Models: Estimation, Calibration, and Data. }\end{array}$ \\
\hline $8107 C$ & Burgess, David F., Energy Prices, Capital Formation, and Potential GNP \\
\hline $8108 C D g$ & $\begin{array}{l}\text { Jimenez, E. and Douglas } \mathrm{H} \text { Keare. Housing Consumption and Income in } \\
\text { the Low Income Urban Setting: Estimates from Panel Data in El Salvador }\end{array}$ \\
\hline 8109 C DSJ & Whalley, John Labour Migration and the North-South Debate \\
\hline $8110 c$ & $\begin{array}{l}\text { Manning, Richard and John McMillan Government Expenditure and } \\
\text { Comparative Advantage }\end{array}$ \\
\hline
\end{tabular}

1982

$8201 C$

Manning, Richard and James R. Markusen Dynamic Non-Substitution and Long Run Production Possibilities

$8202 \mathrm{C}$

Yeenstra, Robert and Ken Judd Tariffs, Technology Transfer, and Welfare

82036

Ronald W. Jones, and Douglas D. Purvis: International Differences in Response to Common External Shocks: The Role of Purchasing Power Parity

$8204 \mathrm{C}$

James A Brander and Barbara J. Spencer: Industrial strategy with Committed Firms

$8205 C$

Whalley, John, The North-south Debate and the Terms of Trade: An npplicd General Equilibrium Approach

8206C Roger Betancourt, Christopher Clague, Arvind Panagariya CAPI TAL UTI LI ZATI ON IN GENERAL EQ UILIBRI UM

$8207 \mathrm{C}$

Mansur, Ahsan $H$ On the Estimation of Import and Export Demand Elasticities and Elasticity Pessimism.

8208C. Whalley, J. and Randy Wigle PRICE AND QUANTITY RIGIDITIES IN ADJUSTMENT TO TRADE YOLICY CHANGES: ALTERNATIVE FORMULATIONS AND INITIAL CALCULATIONS

8209C DSU JImenez, E. SQUATTING AND COMMUNITY ORGANIZATION IN DEVELOPING COUNTRIES: A CONCEPTIUAL FRAMEWORK 
$8210 \mathrm{C}$ Grossman, G.M. INTERNATIONAL COMPETITION AND THE UNIONIZED SECTOR

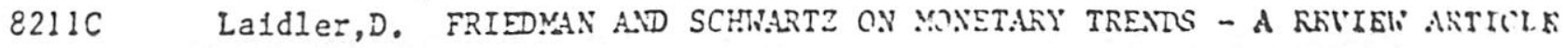

8212C Imam, M.H. and Whalley, J. INCIDENCE ANALYSIS OF A SECTOR SPECIFIC MINIMUM WAGE IN A TWO SECTOR HARRIS-TODARO MODEL.

8213C Markusen, J.R. and Melvin, J.R. THE GAINS FROM TRADE THEOREM WITH INCREASING RETURNS TO SCALE.

8214C INDUSTRIAL ORGANIZATION AND THE GENERAL EQUILIBRIUM COSTS OF PROTECTION IN SMALL OPEN ECONOMIES.

8215C Laidler, D. DID MACROECONOMICS NEED THE RATIONAL EXPECTATIONS REVOLUTION?

8216C Whalley, J. and Wigle, R. ARE DEVELOPED COUNTRY MULTILATERAL TARIFF REDUCTIONS NECESSARILY BENEFICIAL FOR THE U.S.?

8217C Bade, R. and Parkin, M. IS STERLING M3 THE RIGHT AGGREGATE?

8218C Kosch, B. FIXED PRICE EOUUIIBRIA IN OPEN ECONOMIES.

\section{3}

$8301 \mathrm{C}$ Kimbell, L.J. and Harrison, G.W. ON THE SOLUTION OF GENERAL EQUILIBRIUM MODELS.

8302C Melvin, J.R. A GENERAL, EQUILIBRIUM ANALYSIS OF'CANADIAN OIL POLICY.

8303C Markusen, J.R. and Svensson, L.E.0. TRADE IN COODS AND FACTORS WITH INTERNATIONAL DIFFERENCES IN TECHNOLOCY.

830 $4 \mathrm{C}$ Mohamad, S. Whalley, J. RENT SEEKING IN INDIA: ITS COSTS AND POLICY SIGNIFICANCE.

8305C DSU Jimenez, E. TENURE SECURITY AND URBAN SỌUATTING.

8306C Parkin, M. WHAT CAN MACROECONOMIC THEORY TELL US ABOUT THE WAY DEFICITS SHOULD BE MEASURED.

8307C Parkin, M. THE INFLATION DEBATE: AN ATTEMPT TO CLEAR THE AIR.

$8308 \mathrm{C}$ Wooton, I. LABOUR MIGRATION IN A MODEL OF NORTH-SOUTH TRADE.

$8309 \mathrm{C}$ Deardorff, A.V. THE DIRECTIONS OF DEVELOPING COUNTRIES TRADE: EXAMPLES FROM PURE THEORY.

S310C Manning, R. ADVANTAGEOUS REALlOCATIONS AND MULTIPLE EQUILIBRIA: RESULTS FOR THE THREE-AGENT TRANSFER PROBLEM. 
$\underline{1983}$

$8311 C$ DSU Mohamnad, S. and Whalley, J. CONTROLS AND THE INTERSECTORAL TERMS OF TRADE IN INDIA.

8312C Brecher, Richard A. and Choudhr1, Ehsan U. NEW PRODUCTS AND THE FACTOR CONTENT OF INTERNATIONAL TRADE.

8313C Jones, R.W., Neary, J.P. and Ruane, F.P. TWO-WAY CAPITAL FLOWS: CROSSHAULING IN A MODEL OF FOREIGN INVESTMENT.

$8314 C$ DSU Follaln, J.R. Jr. and Jimenez, E. THE DEMAND FOR.HOUSING CHARACTERISTICS IN DEVELOPING COUNTRIES.

8315C Shoven, J.B. and Whalley, J. APPLIED GENERAL EQUILIBRIUM MODELS OF TAXATION AND INTERNATIONAL TRADE.

8316C Boothe, Paul and Longworth David. SOME IRRECULAR REGULARITIES IN THE CANADIAN/U.S. EXCHANGE MARKET.

8317C Hamllton, Bob and Whalley, John. BORDER TAX ADJUSTMENTS AND U.S. TRADE.

8318C Neary, J. Peter, and Schweinberger, Albert G. FACTOR CONTENT FUNCTIONS AND THE THEORY OF INTERNATIONAL TRADE.

$8319 \mathrm{C}$ Veall, Michael R. THE EXPENDITURE TAX AND PROGRESSIVITY.

8320C Melvin, James R. DOMESTIC EXCHANGE, TRANSPORTATION COSTS AND INTERNATIONAL TRADE.

$8321 \mathrm{C}$ Hamllton, Bob and Whalley, John. GEOGRAPHICALLY DISCRIMINATORY TRADE ARRANGEMENTS.

8322C Bale, Harvey Jr. INVESTMEN'T FRICTIONS AND OPPORTUNITIES IN BILATERAL U.S.-CANADIAN TRADE RELATIONS.

8323C Wonnacott, R.J. CANADA-U.S. ECONOMIC RELATIONS--A CANADIAN VIEN.

8324C Stern, Robert M. U.S.-CANADIAN TRADF AND INVESTMENT FRICTIONS: THE U.S. VIEW.

8325C Harrison, Gilenn, H. and Kimbell, Larry, T. HOW ROBUST IS NUMERICAL GENERAL FQUIL.IBRIUM ANALYSIS?

832R. Wonnacote, R.J. THIE TASK FORCIE PROPOSAL ON AUTO CONILNT: WOULD THIS SIMTIY FXXIEND THE $\Lambda U T O$ PACT, OR PUT I'T $\Lambda$ T SERIOUS RISK?

8327C Bradford, James C. CANADIAN DEFENCE TRADE WITH THE U.S. Conklin, David. SUBSIDY PACTS.

Rugman, $\Lambda$ an M. THE BEHAVIOUR OF U.S. SUBSIDARIES IN CANADA: IMI'I.ICATIONS FOR TRADE AND INVESTMENTS. 
8328C Boyer, Kenneth D. U.S.-CANADIAN TRANSPORTATION ISSUES.

8329 C Bird, Richard M. and Brean, Donald J.S. CANADA-U.S. TAX RELATIONS: ISSUES AND PERSPECTIVES.

8330C Moroz, Andrew R. CANADA-UNITEd STATES AUTOMOTIVE TRADE AND TRADE POLICY ISSUES.

8331C Grey, Rodney de C. and Curtis, John. INSTITUTIONAL ARRANGEMENTS FOR U.S.-CANADIAN NEGOTIATIONS. PART I: CANADA-U.S. TRALE AND ECONOMIC ISSUES: DO WE NEED A NEW INSTITUTION? PART II: INSTITUTIONAL ARRANGEMENTS FOR MANAGING THE CANADA-U.S. ECONOMIC REI.ATIONSHIP.

\section{4}

8401C Harrison, Glenn W. and Manning, Richard. BEST APPROXIMATE AGGREGATION OF INPUT-OUTPUT SYSTEMS.

$840^{\circ} \mathrm{C}$ Parkin, Michael. CORE INFLATION: A REVIEW ESSAY.

8403C Blomqvist, Ảke, and McMahon, Gary. SIMULATING COMMERICAL POLICY IN A SMALL, OPEN DUAL ECONOMY WITH URBAN UNEMPLOYMENT: A GENERAL EQQUILIBRIUM APPROACH.

$8404 \mathrm{C}$ Vonnacott, Ronald. THE THEORY OF TRADE DISCRIMINATION: THE MIRROR IMAGE OF VINERIAN PREFERENCE THEORY?

$8405 \mathrm{C}$ Whalley, John. IMPACTS OF A 50\% TARIFF REDUCTION IN AN EIGHT-REGION GLOBAL TRADE MODEL.

8406C Harrison, Glenn W. A GENERAL EQQUILIBRIUM ANALYSIS OF TARIFF REDUCTIONS.

8:07C Horstmann, Ignatius and Markusen, James R. STRATEGIC INVESTMENTS AND THE DEVELOPMENT OF MULTINATIONALS.

8408C Gregory, Allan W. and McCurdy, Thomas H. TESTING THE UNBIASEDNESS HYPOTHESIS IN THE FORIVRD FOREICN EXCHANGE MARKET: A SPECIFICATION ANALYSIS .

8409C Jones, Ronald W. and Kierzkowski, Henryk. NEIGHBORHOOD PRODUCTION STRUCTURES WITH APPLICATIONS TO THE THEORY OF INTERNATIONAL TRADE.

3410C Weller, Paul and Yano, Makoto. THE ROLE OF FUTURES MARKETS IN INTERNATIONAL TRADE: A GENERAL EOUULIBRIUM $\triangle$ PPROACH.

$8411 \mathrm{C}$ Brecher, Richard A. and Bhagwati, Jagdish N. VOLUNTARY EXPORT RESTRICTIONS VERSUS IMPORT RESTRICTIONS: A WELFARE-THEORETIC COMPARISON. 
8412C Ethier, Wilfred J. ILLEGAL IMMIGRATION.

$8413 \mathrm{C}$ Eaton, Jonathon and Gene M. Grossman. OPTIMAL TRADE AND INDUSTRIAL POL ICY UNDER OLIGOPOLY.

8414C Nooton, Ian. PREFERENTIAL TRADING AGREEMENTS - A 3xn MODEL.

$8415 \mathrm{C}$ Parkin, Michael. DISCRIMINATJNG BETWEEN KEYNESIAN AND CLASSICAL THEORIES OF THE BUSINESS CYCLE\& JAPAN 1967-1982

8416C Deardorff, Alan V. FIRless FIRwoes: HOW PREFERENCES CAN INTERFERE WITH THE THEOREMS OF INTERNATIONAL TRADE.

$8417 \mathrm{C}$ Greenwood, Jeremy. NONTRADED GOODS, THE TRADE BALANCE, AND THE BALANCE OF PAYNENTS.

$8418 \mathrm{C}$ Blomqvist, Ake and Sharif Mohammad. CONTROLS, CORRUPTION, AND COMPETITIVE RENT-SEEKING IN LDCs.

$8419 \mathrm{C}$ Grossman, Herschel I. POLICY, RATIONAL EXPECTATIONS, AND POSITIVE ECONOMIC ANALYSIS.

$8420 \mathrm{C}$ Garber, Peter M. and Robert G. King. DEEP STRUCTURAL EXCAVATION? A CRITIOUUE OF EULER EQUATION METHODS.

$8421 \mathrm{C}$ Barro, Robert J. THE BEHAVIOR OF U.S. DEFICITS.

$8422 \mathrm{C}$ Persson, Torsten and Lars E.0. Svensson. INTERNATIONAL BORROWING AND TIME-CONSISTENT FISCAL POLICY.

$8423 \mathrm{C}$ Obstfeld Maurice. CAPITAL CONTROLS, THE DUAL EXChANGE RATE, AND DEVALUATION.

$8424 \mathrm{C}$ Kuhn, Peter. UNION PRODUCTIVITY EFFECTS AND ECONOMIC EFFICIENCY.

8425C Hamilton, Bob and John Whalley. TAX TREATMENT OF HOUSING IN A DYNAMIC SEOQUENCED GENERAL EOUUILIBRIUM MODEL.

$: 426 \mathrm{C}$ Hamilton, Bob, Shartf Mohammad, and John Whalley. RENT SEEKING AND THE NORTH-SOUTH TERMS OF TRADE.

$8427 \mathrm{C}$ Adams, Charles and Jeremy Greenwood. DUAL EXCHANGE RATE SYSTEMS AND CAPITAL CONTROLS: AN INVESTIGATION.

8428 Loh, Choon Cheong and Michael R. Veall. A NOTE ON SOCIAL SECURITY AND PRIVATE SAVINGS IN SINGAPORE.

8429 Whalley, John. RFGRESSION OR PROGRESSION: THE TAXING OUESTION OF INCIDENCE ANALYSIS.

8430 Kuhn, Peter. WAGES, EFFORT, AND INCENTIVE-COMPATIBILITY IN LIFE-CYCLE EMPLOYMENT CONTRACTS. 
8431 Greenwood, Jeremy and Kent P. Kimbrough. AN INVESTIGATION IN THE THEORY OF FOREIGN EXCHANGE CONTROLS.

8432 Greenwood, Jeremy and Kent P. Kimbrough. CAPITAL CONTROLS AND THE INTERNATIONAL TRANSMISSION OF FISCAL POLICY.

8433 : Nguyen, Trien Trien and John Whalley. EỌILIBRIUM UNDER PRICE CONTROLS WITH ENDOGENOUS TRANSACTIONS COSTS.

8434 Adams, Charles and Russell S. Boyer. EFFICIENCY AND A SIMPLE MODEL OF EXCHANGE RATE DETERMINATION.

8435 Kuhn, Peter. UNIONS, ENTREPRENEURSHIP, AND EFFICIENCY.

8436 Hercowitz, Zvi and Efraim Sadka. ON OPTIMAL CURRENCY. SUBSTITUTION POLICY AND PUBLIC PINANCE.

8437 Lenjosek, Gordon and John Whalley. POLICY EVALUATION IN A SMALL OPEN PRICE TAKING ECONOMY: CANADIAN ENERGY POLICIES.

8438 Aschauer, David and Jeremy Greenwood. MACROECONOMIC EFFECTS OF FISCAL POLICY.

8439C Hercowitz, Zvi. ON THE DETERMINATION OF THE EXTERNAL DEBT: THE CASE OF ISRAEL.

8440C Stern, Robert M. GLOBAL DIMENSIONS AND DETERMINANTS OF INTERNATIONAL TRADE AND INVESTMENT IN SERVICES.

8441C Deardorff, Alan V. COMPARATIVE ADVANTAGE AND INTERNATIONAL TRADE AND INVESTMENT IN SERVICES.

8442C Daly, Donald J. TECHNOLOGY TRANSFER AND CANADA'S COMPETITIVE PERFORMANCE.

8443C Grey, Rodney de C. NEGOTIATING ABOUT TRADE AND INVESTMENT IN SERVICES.

8444C Grossman, Gene M. and Carl Shapiro. NORMATIVE ISSUES RAISED BY INTERNATIONAL TRADE IN TECHNOLOGY SERVICES.

3445C Chant, John $\mathrm{F}$. THE CANADIAN TREATMENT OF FOREIGN BANKS: A CASE STUDY IN THE WORKINGS OF THE NATIONAL TREATMENT APPROACH.

8446C Aronson, Jonathan D. and Peter F. Cowhey. COMPUTER, DATA PROCESSING, AND COMMUNICATION SERVICES.

8447C Feketekuty, Geza. NEGOTIATING STRATEGIES FOR. LIBERALIZING TRADE AND INVESTMENT IN SERVICES.

8448C Harrison, Glenn, W. and E.E. Rutstrom. THE EFFECT OF MANUFACTURING SECTOR PROTECTION ON ASEAN AND AUSTRALIA: A GENERAL ENUILIBRIUM ANALYSIS. 
$8501 C$

8502C Horstmann, Ignatius and James R. Markusen. UP YOUR AVERAGE COST CURVE: INEFFICIENT ENTRY AND THE NEW PROTECTIONISM.

8503C Gregory, Allan $W$. TESTING INTEREST RATE PARITY AND RATIONAL EXPECTATIONS FOR CANADA AND THE UNITED STATES. 